\title{
Vegetable Seedling Root Systems: Morphology, Development, and Importance
}

\author{
Daniel I. Leskovar \\ Texas Agricultural Experiment Station, Texas A\&M University, 1619 Garner Field Road, Uvalde, TX 78801 \\ Peter J. Stoffella \\ Agricultural Research and Education Center, Institute of Food and Agricultural Sciences, University of Florida, \\ 2199 South Rock Road, Fort Pierce, FL 34945-3138
}

Seedling root systems have important physical and physiological roles from the onset of seed germination (radicle protrusion) and emergence through subsequent seedling growth and development. Important root functions include shoot anchorage, water uptake, nutrient uptake, and hormone production. The size, morphology, or architecture of a root system may control the relative size and growth rate of the shoot. Optimum root systems throughout the plant life cycle can ensure optimum shoot growth, shoot development, and subsequent yields. However, abiotic stresses originating in the root zone can be expressed in the shoots, thereby affecting the dry-matter partitioning and, ultimately, the productivity of the plant. Understanding the relationships of root and shoot components to stand establishment, particularly as influenced by abiotic stresses, is essential for developing optimum cultural and management techniques for field planting systems.

Selection of root study methods is critical in evaluating associations or relationships among root and shoot components. Root study methods have been developed for destructive and nondestructive sampling. Selection of methodology depends on the crop(s) to be studied, purpose of the investigation, root variables to be measured, time constraints, and costs. Root study methods have been reviewed by Böhm (1979), Schuurman and Goedewaagen (1971), and Taylor (1986). Quantification of roots from image analysis using a minirhizotron has been reviewed by Smucker et al. (1987). Techniques for measuring root geometry using image analysis and resinimpregnated blocks were reported by Commins et al. (1991).

\section{SEEDLING ROOT MORPHOLOGY}

To establish seedling root system relationships with shoot growth or development, a clear understanding of root morphology is required. Klepper and Rickman (1991) described root systems in terms of axes and their branches: 1) vertical or main axes (or taproots), 2) horizontal or vertical axes (first-order laterals), and 3) second- or higher-order laterals. Generally, seedling root morphology differs between monocotyledonous and dicotyledonous species. For example, the seedling root systems of mungbean (Vigna radiata L.), corn (Zea mays L.), and onion (Allium cepa L.) are distinctly different (Fig. 1). Mungbean, a dicotyledonous species, has a defined taproot (originating from the radicle), lateral roots (initiating from the taproot, or pericycle cells), basal roots (originating from the basal part of the hypocotyl or shootroot transition zone when pericycle cells do not originate in this area), and adventitious roots (originating from the hypocotyl). This rootorigin classification was first described by Zobel (1975) for tomato (Lycopersicon esculentum Mill.) and by Stoffella et al. (1979b) for beans (Phaseolus vulgaris L.). Onion, a monocot, has no defined taproot, but only an accumulation of adventitious roots and lateral roots (which originate from the preexisting adventitious roots). However, distinctive root morphological differences occur within monocots (Fig. 1) and dicots. Root systems have been illustrated for fieldgrown vegetable (Weaver and Bruner, 1927) and agronomic crops (Weaver, 1926).

Received for publication 17 Mar. 1995. Accepted for publication 7 Apr. 1995. Texas Agricultural Experiment Station Publication no. TA-31835. Florida Agricultural Experiment Station Journal Series no. R-04311. The cost of publishing this paper was defrayed in part by the payment of page charges. Under postal regulations, this paper therefore must be hereby marked advertisement solely to indicate this fact.
Root dry-weight accumulation, number, diameter, length, surface area, and distribution in a soil profile can differ within crop species. Seedling taproot, basal root, and adventitious root variables differ between genotypes of beans (Kahn et al., 1985; Lynch and van Beem, 1993), peppers (Capsicum annuum L.) (Leskovar et al., 1989; Stoffella et al., 1988a), and mature tomatoes (Stoffella, 1983). In cowpea [Vigna unguiculata (L.) Walp.], 'California Blackeye \#5' seedlings had longer taproots, more lateral roots, taller shoots, and heavier roots and shoots than 'Knuckle Purple Hull' or 'Texas Cream 40' seedlings when measured 11 days after radicle protrusion (Table 1). Mean taproot growth rate (length) and lateral root production from 3 to 11 days after radicle protrusion also differed among these three cowpea cultivars (Table 2).

Root architectural traits, such as secondary and tertiary root branching, angles, and radii, also should be considered in evaluating seedling root systems. Fitter $(1987,1991)$ reported an architectural approach to studying plant root systems and suggested that topological models and architectural root system components, such as link lengths, branching angles, and diameters, should be used for comparative ecological studies of plant root systems. Detecting differences in root growth patterns and architecture between genotypes may offer unique genetic selection criteria for tolerance to root diseases and pests, lodging, drought, flooding, stressful root-zone temperatures, or edaphic adaptations. Reviews of genotypic variation in root morphological characteristics and variation in root system phenotypes have been reported by O'Toole and Bland (1987), and of rhizogenetic variation in vegetable crops by Zobel $(1975,1986)$. Root morphological traits can be directly related to plant lodging (Ennos, 1990; Kahn, 1985; Stoffella and Kahn, 1986; Stoffella et al., 1979a), flooding tolerance (Kahn et al., 1985), and nodule formation (Kahn and Stoffella, 1991). Zobel (1989) has reviewed studies on the effects of edaphic and environmental factors, such as moisture, temperature, mineral concentration, and gaseous atmosphere, on root morphology. O'Toole and Bland (1987) also emphasized the importance of specific root morphological traits and their importance in improving or overcoming physiological stresses.

\section{SEEDLING ROOT DEVELOPMENT}

Minimal research has focused on the development of seedling root systems and implications for optimum stand establishment and subsequent seedling shoot growth and development. Previous investigations have addressed improvement in percent or rate of seed germination and seedling emergence via seed enhancement treatments, research that has been extensively reviewed by Bradford (1986), Khan (1992), and Heydecker and Coolbear (1977).

Initiation, organization, and emergence of lateral roots are complex processes involving growth regulators and specific gene expression (Keller and Lamb, 1989; Wightman et al., 1981). Auxin transported from the cotyledons has a controlling role in the position, spacing, and development of lateral root primordia in peas (Pisum sativum L.) (Hinchee and Rost, 1992). In peas, the first lateral roots are initiated in the radicle before germination (Rost and Toriyama, 1991). After seeding, initiation of root primordia on the primary root and hypocotyl of tomato seedlings varied between genotypes and the number of primordia on the primary root and hypocotyl was increased either by Hoagland's solution or by presoaking seeds with abscisic acid (ABA) or 6-benzylamino purine (BA) (Aung, 1982). Treatments with 3indolylacetic acid (IAA) or other auxins promoted the initiation of the 


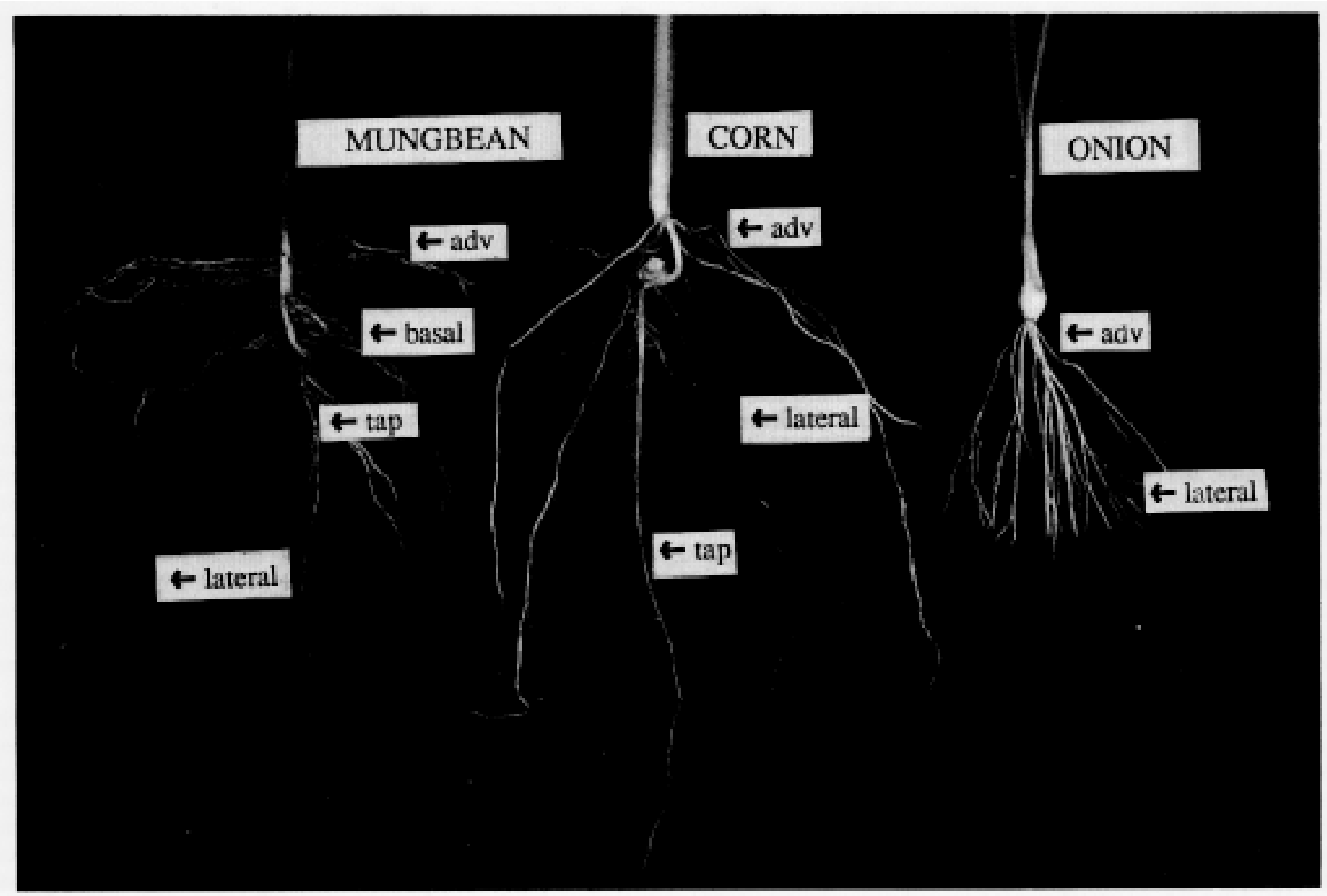

Fig. 1. Root morphological components of mungbean, corn, and onion seedlings depicting adventitious (adv), basal, lateral, and taproots (tap).

Table 1. Cowpea taproot length, lateral root number, fresh root weight, fresh shoot weight, and shoot : root ratio 11 days after radicle protrusion (data on a per plant basis).

\begin{tabular}{|c|c|c|c|c|c|c|c|c|c|c|c|c|}
\hline Cultivar & $\begin{array}{c}\text { Taproot } \\
\text { length } \\
(\mathrm{cm})\end{array}$ & $\mathrm{CV}^{\mathrm{z}}$ & $\begin{array}{c}\text { Lateral } \\
\text { root } \\
\text { (no.) }\end{array}$ & $\mathrm{CV}$ & $\begin{array}{c}\text { Root } \\
\text { wt } \\
(\mathrm{mg}) \\
\end{array}$ & $\mathrm{CV}$ & $\begin{array}{c}\text { Shoot } \\
\text { wt } \\
(\mathrm{mg}) \\
\end{array}$ & $\mathrm{CV}$ & $\begin{array}{c}\text { Shoot: } \\
\text { root } \\
\text { (ratio) }\end{array}$ & $\mathrm{CV}$ & $\begin{array}{c}\text { Shoot } \\
\text { ht } \\
(\mathrm{cm})\end{array}$ & $\mathrm{CV}$ \\
\hline \multicolumn{13}{|l|}{ California } \\
\hline Blackeye \#5 & $27.7 \mathrm{a}^{\mathrm{y}}$ & 18 & $126 \mathrm{a}$ & 27 & $0.57 \mathrm{a}$ & 41 & $1.42 \mathrm{a}$ & 26 & 2.94 & 48 & $16.5 \mathrm{a}$ & 33 \\
\hline \multicolumn{13}{|l|}{ Knuckle } \\
\hline Purple Hull & $12.6 \mathrm{c}$ & 47 & $51 \mathrm{c}$ & 49 & $0.41 \mathrm{~b}$ & 36 & $1.14 \mathrm{~b}$ & 17 & 3.05 & 35 & $13.5 \mathrm{~b}$ & 19 \\
\hline \multicolumn{13}{|l|}{ Texas } \\
\hline Cream 40 & $19.2 \mathrm{~b}$ & 36 & $70 \mathrm{~b}$ & 36 & $0.24 \mathrm{c}$ & 46 & $0.71 \mathrm{c}$ & 27 & 3.32 & 34 & $11.5 \mathrm{c}$ & 19 \\
\hline
\end{tabular}

${ }^{2}$ Coefficient of variation (\%).

yMean separation within columns by Duncan's multiple range test, $P \leq 0.05$.

Table 2. Linear regression equations of mean taproot length or total number of lateral roots on days after radicle protrusion (3-11 days) of three cowpea cultivars.

\begin{tabular}{lccc}
\hline \hline Cultivar & $\begin{array}{c}\text { Regression } \\
\text { equation }\end{array}$ & $R^{2}$ & CV $^{\mathrm{y}}$ \\
\hline California Blackeye \#5 & $\begin{array}{c}\text { Taproot length } \\
-6.9+3.4 \mathrm{D}^{\mathrm{x}}\end{array}$ & 0.86 & 21 \\
Knuckle Purple Hull & $-2.1+1.4 \mathrm{D}$ & 0.46 & 51 \\
Texas Cream 40 & $-5.5+2.3 \mathrm{D}$ & 0.72 & 35 \\
& No. lateral roots & & \\
California Blackeye \#5 & $-64.1+17.9 \mathrm{D}$ & 0.80 & 38 \\
Knuckle Purple Hull & $-22.8+6.8 \mathrm{D}$ & 0.63 & 54 \\
Texas Cream 40 & $-33.4+9.0 \mathrm{D}$ & 0.71 & 51 \\
\hline
\end{tabular}

${ }^{\mathrm{z}} \mathrm{D}=$ days after radicle protrusion.

${ }^{y}$ Coefficient of variation (\%).

${ }^{x}$ Regression coefficients (slopes) are significantly different from each other by $t$ tests, $P \leq 0.05$. lateral root primordia in peas (Wightman et al., 1981) and increased the number of primordia formed along the primary axis in peas (Zeadan and MacLeod, 1984) and corn (Hurren et al., 1988). MacIsaac et al. (1989) reported that 2-naphthaleneacetic acid (NAA) increased the number of lateral root primordia, but kinetin prevented their spontaneous formation and inhibited the NAA-enhanced lateral root primorida of lettuce (Lactuca sativa L.). In corn, most primordia from the primary root completed their development and emerged as laterals within a fixed period, irrespective of their origin along the main axis (MacLeod, 1990). Cytokinins, particularly zeatin, inhibited the initiation and formation of lateral roots on decapitated primary roots of pea seedlings (Wightman et al., 1981). Removal of adventitious root tips promoted the formation of primordia along most of the remaining axis in onion seedlings (Abadia-Fenoll et al., 1986); however, normal onion roots appeared to be unbranched (Fig. 1) over distances of up to $400 \mathrm{~mm}$ from the apex (Melchior and Steudle, 1993).

Root developmental sequence in bell pepper has been reported as 
radicle protrusion from the seed, rapid taproot elongation until cotyledon development, and production of basal and lateral roots subsequent to cotyledon expansion (Stoffella et al., 1988a). Medium pH (Stoffella, et al., 1991), seed enhancement treatments (Stoffella et al., 1988b, 1992), and temperature (Stoffella et al., 1988b) influenced pepper seedling root system development. Portas and Dordio (1980) have reviewed investigations on root length, width, depth, and density of tomatoes. Tanaka (1964) classified root development of legume crops into alfalfa (Medicago sativa L.), vetch (Vicia spp.), and intermediate [soybean, Glycine max (L.) Marr.] types. Tanaka (1977) also reported that root elongation, branching, and thickening ability differed among 26 legume crops. Models developed from derived equations of root (length) density in relation to shoot weight for several vegetable crops were described by Greenwood et al. (1982).

\section{STRESS EFFECTS ON SEEDLING GROWTH}

The abiotic root-soil environment is seldom optimum for continuous growth and can have a profound influence on root anatomical characteristics, root developmental patterns, and the seedling physiology of roots. Root systems in relation to stress tolerance have been reviewed by Miller (1986), who discussed the effects of water, $\mathrm{O}_{2}$, mechanical impedance, and temperature stress on mature plants. Latimer (1991) reviewed vegetable seedling growth responses to mechanical stress. Adverse environments that include the interaction of factors such as nonoptimum temperature, deficiency or imbalance of nutrients, drought, and waterlogging have received less attention in seedlings.

\section{Temperature}

Early root elongation, branching, and function are highly temperature-dependent mechanisms (Russell, 1977). Results from root studies conducted at constant temperatures are difficult to extrapolate to estimates of root responses in the field due to fluctuating air and soildepth temperatures. No lateral roots developed for 12 legumes exposed to constant 10 or $30 \mathrm{C}$, and lateral and taproot elongation were highly variable between 15 and 25C (Brar et al., 1990). Taproot elongation rate was slower for pregerminated than for raw or primed pepper seeds incubated at $15 \mathrm{C}$, but similar at 25 or $35 \mathrm{C}$ (Stoffella et al., 1988b).

Root systems of tropical or subtropical origin species are sensitive to chilling temperatures. For example, root growth decreased when squash (Cucurbita pepo L. var. melopepo) and cucumber (Cucumis sativus L.) seedlings were exposed to 2 and $6 \mathrm{C}$ for $48 \mathrm{~h}$, and when seedlings were returned to $26 \mathrm{C}$, irreversible damage (inability to resume growth) occurred after $96 \mathrm{~h}$ (Reyes and Jennings, 1994). Shortterm cyclic cold stresses (2C) before transplanting generally stimulated seedling height, leaf area, and shoot and root growth, but decreased chlorophyll content in tomato seedlings (Dufault and Melton, 1990). Temperatures between 10 to $13 \mathrm{C}$ suppressed tomato root growth (Hardenburg et al., 1986). However, Leskovar and Cantliffe (1991) reported that stem length, and root fresh and dry weights were not suppressed when containerized tomato transplants were stored at $5 \mathrm{C}$ for 8 days. When containerized tomato seedlings were transplanted and mulched in beds with clear polyethylene, seedling root extension rates between 1 to 2 weeks after transplanting were significantly correlated with soil temperature during the first week (Wien et al., 1993).

Temperature directly influences the nutrient status of seedlings by affecting nutrient absorption and transport from the roots to the shoots. Seedling root elongation of beans, cucumber, eggplant (Solanum melongena L.), pea, pepper, radish (Raphanus sativus L.), and spinach (Spinacia oleracea L.) was optimum when constant in the 16.7 to 21.1C range, and a synergistic effect with $\mathrm{P}$ nutrition occurred on beans, cucumber, eggplant, and pepper, but not on radish, spinach, and pea (Wilcox and Pfeiffer, 1990). Enhanced early root growth and nutrition uptake, particularly $\mathrm{P}$, characterized tomato transplants grown with clear polyethylene mulch where soil temperatures were 5 to $7 \mathrm{C}$ higher than soil not mulched (Wien et al., 1993). Papadopoulos and Tiessen (1987) reported that leaf tissue accumulation of nutrients at high root temperatures (27 vs. 21C) was greater for $\mathrm{P}$ than for $\mathrm{N}$, with minimum or no effect on the accumulation of $\mathrm{K}, \mathrm{Ca}$, and $\mathrm{Mg}$.

\section{Nutrition, salinity, and pH}

Seedlings have a high demand for mineral nutrients, which, in part, is thought to be a result of their fast growth rates relative to mature plants (Widders and Lorenz, 1982). A strategy used to facilitate root growth, minimize transplant shock, and increase seedling survival is to enhance the seedling nutrient content before transplanting (Dufault, 1986). This technique, known as pretransplant nutritional conditioning (PNC), recently has been reviewed by Dufault (1994). While pretransplant treatment with $\mathrm{P}$ did not enhance shoot growth of tomato seedlings, root initiation and growth were stimulated by $\mathrm{N}$ and $\mathrm{P}$ pretransplant treatments (Garton and Widders, 1990; Widders, 1989). In five bell pepper genotypes, total and basal root length increased linearly with increasing $\mathrm{N}$ rates from 56 to $112 \mathrm{mg} \cdot \mathrm{liter}^{-1}$ when measured 40 days after seeding (Leskovar et al., 1989). Localized feeding of $\mathrm{NO}_{3}$ stimulated lateral root initiation in corn (Granato and Raper, 1989). Shoot : root ratio in tomato seedlings was reduced from 4.0 to 2.3 when $\mathrm{N}$ rate was decreased from 400 to $100 \mathrm{mg} \cdot \mathrm{liter}^{-1}$ regardless of $P$ rate (15 to $60 \mathrm{mg} \cdot \mathrm{liter}^{-1}$ ) (Weston and Zandstra, 1989). Small shoot : root ratio differences occurred on cauliflower (Brassica oleracea $\mathrm{L}$. Botrytis Group) seedlings exposed to $\mathrm{N}$ rates between 0 and 155 mg.liter ${ }^{-1}$ (Booij, 1992). Increasing $\mathrm{N}$ rates between 150 to $350 \mathrm{mg} \cdot \mathrm{liter}^{-1}$ increased shoot dry weight and shoot : root ratio, but decreased root dry weight in celery (Apium graveolens L.) seedlings (Tremblay and Gosselin, 1989). Barker (1989) has cited several investigations in which root morphology was found to be associated with root affinity for $\mathrm{NO}_{3}$ or $\mathrm{NH}_{4}$, root ability to discriminate between $\mathrm{NO}_{3}$ or $\mathrm{NH}_{4}$, and root detoxification of $\mathrm{NH}_{4}$.

Root growth is generally less sensitive to salinity than shoot growth (Lauchli and Epstein, 1990), as reflected by lower shoot : root ratios when salinity is increased. However, salinity effects on root systems can be significant. For example, Snapp and Shennan (1992) reported that root-length density of two tomato cultivars (CX8303, root-rot tolerant to Phytophtora parasitica Dast., and UC82B, sensitive to root rot) was reduced between $21 \%$ and $39 \%$ at a moderate salinity level of $75 \mathrm{~mm} \mathrm{NaCl}$ plus $\mathrm{CaCl}_{2}$ (4 Na : 1 Ca molar ratio) as compared to $3 \mathrm{~mm}$. Calcium plays an important role in adapting seedling plant tissue to saline conditions (Kent and Lauchli, 1985). Calcium also has a role in the root cap in regulating root growth and is translocated to the shoots mainly from young roots (Russell, 1977). Harrison-Murray and Clarkson (1973) indicated that absorption and translocation were greater within $3 \mathrm{~cm}$ of the root apex in taproots of marrow (Cucurbita pepo L.) than in more distal positions. Takahashi et al. (1992) reported that exogenous $\mathrm{Ca}^{2+}$ applied at 10 or $20 \mathrm{~mm}$ directly to the root cap stimulated root elongation in pea and corn seedlings. They suggested that differences in responsiveness of roots to $\mathrm{Ca}^{2+}$ may result from water conditions at the root tip that differ from those along the older portions. Inhibitory effects of $100 \mathrm{~mm} \mathrm{NaCl}$ on maize root elongation were partially reversed by $\mathrm{Ca}^{2+}$ levels at $10 \mathrm{~mm}$ in the root medium, as evidenced by increasing root diameter and root hydraulic conductivity in the apical $4 \mathrm{~cm}$ of the primary roots (Azaizeh et al., 1992; Evlagon et al., 1992).

Root and shoot weights were higher and taproot growth rate was faster for bell pepper seedlings grown at $\mathrm{pH} 5.9$ as compared with $\mathrm{pH}$ 4.0 or 7.3 (Stoffella et al., 1991). Plant roots increased (Liu, 1980; Marschner et al., 1986) or decreased rhizosphere $\mathrm{pH}$ (Grünsted et al., 1982; Schaller, 1987). Rhizosphere $\mathrm{pH}$ changes are influenced by soil buffering capacity (Schaller, 1987), mineral absorption capacity, absorption efficiency of the plant species (Marschner and Romheld, 1983), and initial soil pH (Youssef and Chino, 1989).

\section{Water}

Effect on root growth. Root activity throughout the soil profile has been investigated for water uptake (Klepper, 1990). Water potential of the root medium influences root growth and the water potential gradient between the medium and root. Significant root elongation restrictions occur when soil water potential is below $-0.8 \mathrm{MPa}$ (Klepper, 
Table 3. Root and shoot characteristics of 'Texas Grano 1015Y' onion transplants in response to cell volume of transplant flat and transplant age, Uvalde, Texas.

\begin{tabular}{|c|c|c|c|c|c|c|c|}
\hline \multirow{2}{*}{$\begin{array}{l}\text { Cell } \\
\text { size } \\
\left(\mathrm{cm}^{3}\right)\end{array}$} & \multirow[b]{2}{*}{$\begin{array}{c}\text { Age } \\
\text { (weeks) }\end{array}$} & \multicolumn{2}{|c|}{ Root } & \multirow{2}{*}{$\begin{array}{l}\text { Bulb } \\
\text { diam } \\
(\mathrm{mm})\end{array}$} & \multicolumn{2}{|c|}{ Shoot } & \multirow{2}{*}{$\begin{array}{r}\text { Shoot } \\
\text { root } \\
\text { ratio }\end{array}$} \\
\hline & & No. & $\begin{array}{c}\text { Dry wt } \\
(\mathrm{mg})\end{array}$ & & $\begin{array}{l}\text { Leaf } \\
\text { (no.) }\end{array}$ & $\begin{array}{c}\text { Dry wt } \\
(\mathrm{mg})\end{array}$ & \\
\hline \multirow[t]{4}{*}{$\overline{7.1^{z}}$} & 6 & 19.6 & 5.5 & 3.7 & 3.9 & 23.0 & 4.2 \\
\hline & 8 & 25.0 & 9.3 & 4.1 & 4.3 & 33.9 & 3.7 \\
\hline & 10 & 32.0 & 11.6 & 4.3 & 4.8 & 40.5 & 3.5 \\
\hline & 12 & 36.6 & 21.1 & 5.7 & 5.9 & 73.6 & 3.5 \\
\hline Significance & & $\mathrm{L}^{* *}$ & $\mathrm{Q}^{* * *}$ & $\mathrm{Q}^{*}$ & $\mathrm{~L}^{* *}$ & $\mathrm{Q}^{*}$ & NS \\
\hline \multirow[t]{4}{*}{$4.0^{z}$} & 6 & 18.3 & 5.0 & 3.2 & 3.6 & 22.1 & 4.5 \\
\hline & 8 & 28.2 & 8.2 & 4.2 & 4.4 & 29.0 & 3.6 \\
\hline & 10 & 30.8 & 9.1 & 3.8 & 4.4 & 30.5 & 3.4 \\
\hline & 12 & 41.9 & 15.6 & 4.7 & 5.5 & 50.4 & 3.3 \\
\hline Significance & & $\mathrm{L}^{*}$ & $\mathrm{Q}^{*}$ & $\mathrm{~L}^{* *}$ & NS & NS & NS \\
\hline
\end{tabular}

${ }^{2}$ Transplant flats O80A and 595M contained 338 and 595 cells, respectively. Samples were taken at time of transplanting, 8 Dec. 1993. Ns, *,**Nonsignificant or significant $\mathrm{F}$ test at $P \leq 0.05$ or 0.01 , respectively. Significant age effects were linear (L) or quadratic (Q).

1991). Although taproots have the capacity to explore deep layers of the soil profile, under drought conditions, monocot and dicot seedlings may also highly depend for survival and subsequent growth on crown (or nodal), adventitious, basal, or lateral roots. In maize, the water potential at which growth stopped was $-0.5,-1.0$, and $-1.4 \mathrm{MPa}$ for stems, leaves, and nodal roots, respectively (Westgate and Boyer, 1985).

Water flux is a function of water potential differences and hydraulic conductances (Melchior and Steudle, 1993). In dry surface soils, roots may develop strong axial and radial resistance to the pathway of water flow from root to shoot tissues (Cornish et al., 1984; Steudle et al., 1987). The main resistance to water flux lies in the radial pathway (from the soil solution to the tracheary elements) and not in the axial path (within the tracheary elements) (Frensch and Steudle, 1989).
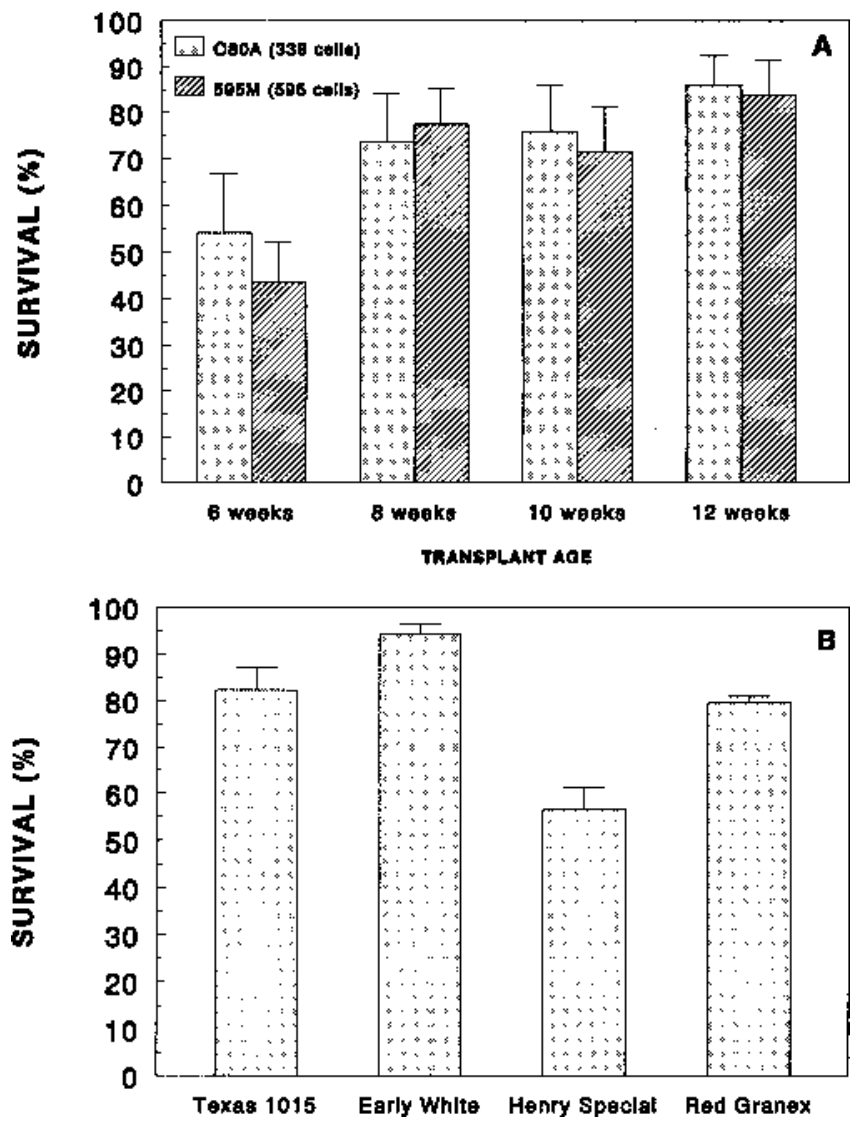

Fig. 2. (A) Field survival of onion transplants grown in O80A and 595M (7.1and $4.0-\mathrm{cm}^{3}$ cells, respectively) transplant flats in response to transplant age. Transplants were set in the field on 8 Dec. 1993. Error bars represent a mean \pm SE. (B) Field survival of onion transplants grown in 595M transplant flats as influenced by cultivar. Transplants were set in the field on 20 Dec. 1993 and were exposed to freezing temperatures $(-3$ to $-5 C) 1$ week after transplanting.
McCully and Canny (1988) reported that the diameters of the largest nonoccluded tracheary element(s) are the most important characteristic influencing hydraulic conductivity. The number of first-order branch roots and the diameter of their largest tracheary element differed at nodes along the root axes of corn (Varney et al., 1991).

Drought stress and abscisic acid (ABA). Pepper seedlings exposed to mild drought conditions had lower root dry weight, basal root number and diameter, and shoot growth as compared with wellwatered seedlings (Leskovar and Cantliffe, 1992; Watts et al., 1981). The influence of drought stress on root and shoot growth is mediated by endogenous changes in ABA concentration acting as a signal for control of growth processes (Davis et al., 1986). ABA synthesis induced by water stress has been correlated with a reduction of shoot : root ratio either by shoot growth reduction (Creelman et al.,
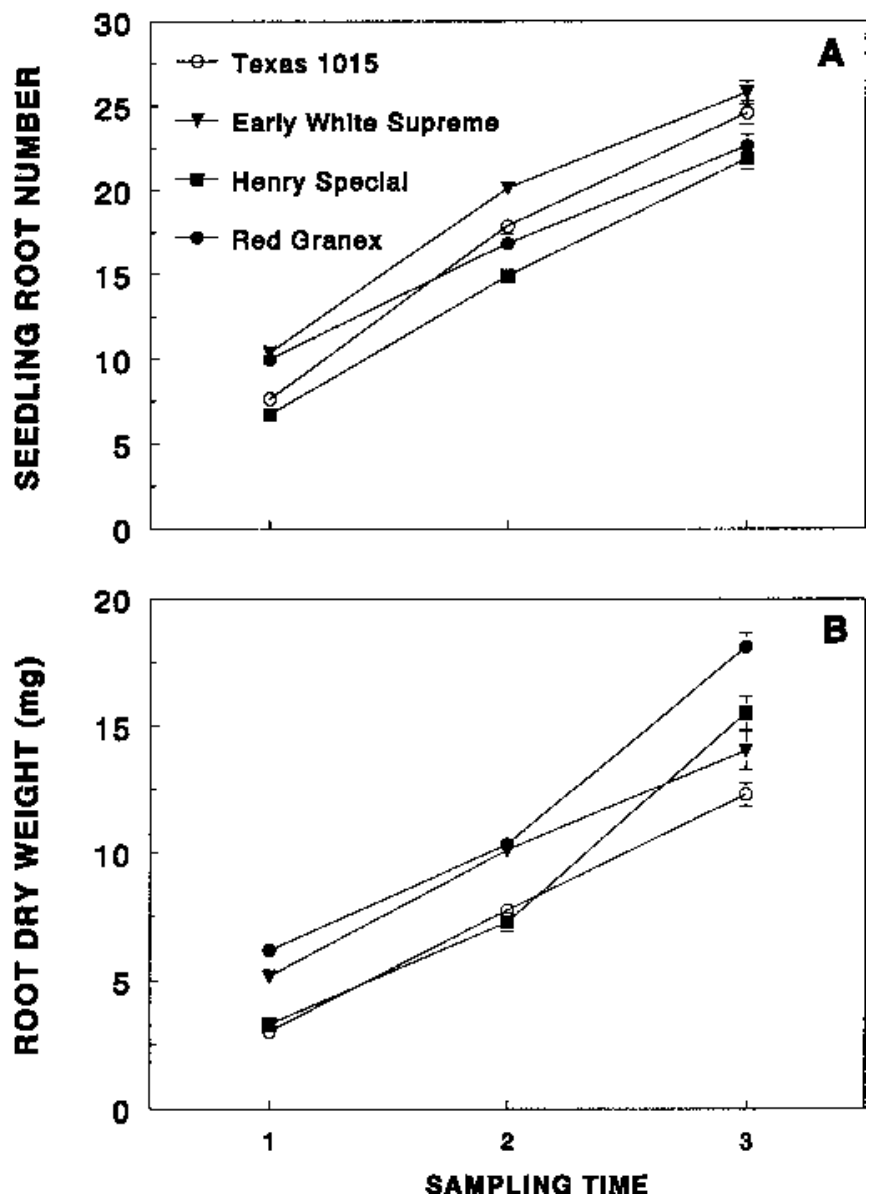

Fig. 3. (A) Seedling root number and (B) seedling root weight of onion cultivars. Seedlings were seeded in $595 \mathrm{M}$ transplant flats $\left(4.0-\mathrm{cm}^{3}\right.$ cells $)$ on 19 Oct. 1993. Sampling times 1, 2, and 3 correspond to 11 and 29 Nov. and 16 Dec. 1993. 
1990) or by more root growth relative to shoot growth (Karmoker and Van Steveninck, 1979). ABA was studied as a substitute for drought stress to control seedling growth and improve transplant field establishment in pepper and eggplant seedlings. When ABA was applied at $10^{-4} \mathrm{M}$ to pepper seedlings 3 weeks after seeding, there was a transient inhibition of leaf weight increase, but root growth was unaffected (Leskovar and Cantliffe, 1992). ABA at $10^{-3} \mathrm{M}$ reduced relative growth rates of eggplant seedlings (Latimer and Mitchell, 1988). Increased seedling survival due to exogenous application of ABA was related to increased leaf resistance and leaf water potential in pepper seedlings (Berkowitz and Rabin, 1988).

Flooding. Soil flooding limits the diffusion of $\mathrm{O}_{2}$ to the root zone (Bradford and Yang, 1981; Drew, 1992), affecting young plants with a high percentage of primary roots as compared to more mature roots in older plants (Letey et al., 1962). Adventitious roots play a major role in the survival of many mesophytes by partially replacing the functions of the original roots (Jackson and Drew, 1984). Aloni and Rosenshtein (1982), Jackson (1955) (1979), and Kramer (1951) reported that flooding-induced root injury is limited if adventitious roots develop, indicating that these roots are important for recovery of shoot growth following flooding. Kahn et al. (1985) reported that adventitious roots became the predominant root component (highest weight as compared to taproot or basal roots) after bean seedlings were exposed to 7 days of flooding, followed by 7 days of recovery. Similarly, in continuously flooded tomato cultivars, adventitious roots accounted for more than $50 \%$ of the total root mass (Poysa et al., 1987). However, adventitious root development did not overcome flooding injury of sunflower (Helianthus annum L.) (Wample and Reid, 1978).

\section{ESTABLISHMENT METHODS: EFFECT ON ROOT DEVELOPMENT}

Seedling establishment in any field environment depends on the adequate development of a taproot, associated laterals, and basal roots for dicot species, or adventitious roots and associated lateral roots for most monocot species. Root growth patterns of plants established by direct seeding differ from those of plants established by transplanting. Direct-seeded plants develop a strong taproot (Weaver and Bruner, 1927), while transplants develop a distinctive root system caused by modification of the taproot (McKee, 1981) and subsequent development of lateral and basal roots (Leskovar et al., 1989; Stoffella et al., 1988a). Direct-seeded pepper plants, established with primed or raw seeds, had variable root growth over time as compared with a constant rate of root growth from transplants (Leskovar et al., 1990). Early root development was unaffected by seed priming in pepper (Stoffella et al., 1992), and total root growth (dry-weight basis) was similar for primed or untreated pepper plants when measured at maturity (Leskovar et al., 1990). Basal, lateral, and taproot dry weights accounted for $81 \%$, $15 \%$, and $4 \%$, respectively, of the total root dry weights for containerized transplants and $25 \%, 57 \%$, and $18 \%$, respectively, of the total root dry weights for direct-seeded bell pepper plants (Leskovar and Cantliffe, 1993). The latter also exhibited greater root relative growth rates and total root growth than transplants. As a consequence, transplanted pepper plants may be more prone to lodging than direct-seeded plants. Cooksey et al. (1994) reported that the force to uproot pepper plants established by transplanting was $15 \%$ lower than for plants established by direct seeding.

Transplant production systems, including flotation and overhead irrigation, also influenced root and shoot growth characteristics in bell pepper and tomato seedlings in the greenhouse (Leskovar and Cantliffe, 1993; Leskovar et al., 1994). In jalapeño peppers, overhead irrigation enhanced basal root elongation and root weight as compared with seedlings grown with flotation irrigation; however, the flotation irrigation system improved water-use efficiency, reduced shoot : root ratio, and promoted seedling hardiness (Leskovar and Heineman, 1994). Providing uniform moisture levels around the hypocotyl during the last 2 weeks before field establishment is also thought to enhance basal root primordia development in transplants. The importance of basal root development in the field has been emphasized in peppers (Leskovar and Cantliffe, 1993), black beans (Stoffella et al., 1979a), and tomatoes (Zobel, 1975).
The ability of a transplant (bareroot or containerized) to overcome transplant shock and become established in a field environment following transplanting depends on how seedlings withstand root disturbance (McKee, 1981), and how water and nutrient uptake capacity of the roots and the capacity of the preexisting roots to rapidly regenerate new lateral, basal, or adventitious roots are affected. Root pruning before transplanting tomatoes delayed reestablishment (McKee, 1981), and the net rate of root and shoot biomass increase was limited (Leskovar et al., 1994). Enhanced early tomato root growth and nutrient uptake are key factors in increasing shoot growth (Wien et al., 1993).

Early root and shoot seedling response to various cultural systems and environments also depends on the physiological state of the seedlings. Under favorable field conditions, young tomato transplants had a higher relative root growth rate and greater capacity to resume shoot growth than older transplants (Leskovar and Cantliffe, 1991; Weston and Zandstra, 1989). Under windy or sandblasting conditions, older tomato seedlings survived better than young seedlings (Liptay, 1987). Older onion transplants, with more root and shoot growth (Table 3), had higher survival rates compared to younger seedlings when exposed to low winter temperatures after transplanting (Fig. 2A). Survival can also depend on the cultivar (Fig. 2B) and differences in root characteristics between cultivars. For example, root counts were higher, but dry weights lower, for onion cultivars Texas 1015 and Early White Supreme than for cultivars Henry Special and Red Granex (Fig. $3 \mathrm{~A}$ and B).

Information on the effects of establishment methods (direct-seeding or transplanting) or seed enhancement treatments of vegetable crops on subsequent seedling root growth, development, or architecture is limited. The influence of cultural practices on mature root systems has been reported for various vegetables; e.g., plant population density on root morphological characteristics in beans and peppers (Kahn et al., 1981; Stoffella et al., 1981; Stoffella and Bryan, 1988); establishment methods on tomato and pepper root growth (Leskovar and Cantliffe, 1993; Leskovar et al., 1994); irrigation on lettuce root elongation, weight, and diameter (Rowse, 1974); irrigation on root length and density in tomato (Sanders et al., 1989); and irrigation on root distribution of sweet corn (Phene et al., 1991).

\section{CONCLUSIONS}

Investigations are needed on seed enhancement treatments and environmental influences after radicle protrusion to understand implications to further root system development and, ultimately, stand establishment and seedling growth. Few investigations have focused on variability of growth and development of root systems or root components. Genetic or environmental influences on root variability need further exploration. Root study methods and statistical procedures need to be improved or developed to further understand seedling root morphology, architecture, and development. Rhizogenetics, plant root physiological roles and functions, and root architecture investigations can clearly assist in defining the importance of seedling root system components to stand establishment and subsequent development of the shoot system.

\section{Literature Cited}

Abadia-Fenoll, F., P.J. Casero, P.G. Lloret, and M.R. Vidal. 1986. Development of lateral primordia in decapitated adventitious roots of Allium cepa. Ann. Bot. 58:103-107.

Aloni, B. and G. Rosenshtein. 1982. Effect of flooding on tomato cultivars: The relationship between proline accumulation and other morphological and physiological changes. Physiol. Plant. 56:513-517.

Aung, L.H. 1982. Root initiation in tomato seedlings. J. Amer. Soc. Hort. Sci. 107:1015-1018.

Azaizeh, H., B. Gunse, and E. Steudle. 1992. Effects of $\mathrm{NaCl}$ and $\mathrm{CaCl}_{2}$ on water transport across root cells of maize (Zea mays L.) seedlings. Plant Physiol. 99:886-894.

Barker, A.V. 1989. Genotypic response of vegetable crops to nitrogen nutrition. HortScience 24:584-591.

Berkowitz, G.A. and J. Rabin. 1988. Antitranspirant associated abscisic acid effects on the water relations and yield of transplanted bell peppers. Plant Physiol. 86:329-331. 
Böhm, W. 1979. Methods of studying root systems. Springer-Verlag, Berlin.

Booij, R. 1992. Effects of nitrogen fertilization during raising of cauliflower transplants in cellular trays on plant growth. Netherlands J. Agr. Sci. 40:4350.

Bradford, K.J. 1986. Manipulation of seed water relations via osmotic priming to improve germination under stress conditions. HortScience 21:11051112.

Bradford, K.J. and S.F. Yang. 1981. Physiological responses of plants to waterlogging. HortScience 16:25-30.

Brar, G.S., F.G. Gomez, B.L. McMichael, A.G. Matches, and H.M. Taylor. 1990. Root development of 12 forage legumes as affected by temperature. Agron. J. 82:1024-1026.

Cooksey, J.R., B.A. Kahn, and J.E. Motes. 1994. Plant morphology and yield of paprika pepper in response to method of stand establishment. HortScience 29:1282-1284.

Commins, P.J., A.B. McBratney, and A.J. Koppi. 1991. Development of a technique for the measurement of root geometry in the soil using resinimpregnated block and image analysis. J. Soil Sci. 42:237-250.

Cornish, P.S., J.R. McWilliam, and H.B. So. 1984. Root morphology, water uptake, growth and survival of seedlings of ryegrass and phalaris. Austral. J. Agr. Res. 35:479-492.

Creelman, R.A., H.S. Mason, R.J. Bensen, J.S. Boyer, and J.E. Mullet. 1990 Water deficit and abscisic acid cause differential inhibition of shoot versus root growth in soybean seedlings. Plant Physiol. 92:205-214.

Davis, W.J., J. Metcalfe, T.A. Costa, and A.R. da Costa. 1986. Plant growth substances and the regulation of growth under drought. Austral. J. Plant Physiol. 13:105-125.

Drew, M.C. 1992. Soil aeration and plant root metabolism. Soil Sci. 154:259268.

Dufault, R.J. 1986. Influence of nutritional conditioning on muskmelon transplant quality and early yield. J. Amer. Soc. Hort. Sci. 111:698-703.

Dufault, R.J. 1994. Long-term consequences and significance of short-term pretransplant nutritional conditioning. HortTechnology 4:41-42.

Dufault, R.J. and R.R. Melton. 1990. Cyclic cold stresses before transplanting influence tomato seedling growth, but not fruit earliness, fresh market yield, or quality. J. Amer. Soc. Hort. Sci. 115:559-563.

Ennos, A.R. 1990. The anchorage of leek seedlings: The effect of root length and soil strength. Ann. Bot. 65:409-416.

Evlagon, D., I. Ravina, and P.M. Neumann. 1992. Effects of salinity stress and calcium on hydraulic conductivity and growth in maize seedling roots. J. Plant Nutr. 15:795-803.

Fitter, A.H. 1987. An architectural approach to the comparative ecology of plant root systems. New Phytol. 106(suppl.):61-77.

Fitter, A.H. 1991. Characteristics and functions of root systems, p. 3-24. In: Y. Waisel, A. Eshel, and U. Kafkafi (eds.). Plant roots, the hidden half. Marcel Dekker, New York.

Frensch, J. and E. Steudle. 1989. Axial and radial hydraulic resistance to roots of maize (Zea mays L.). Plant Physiol. 91:719-726.

Garton, R.W. and I.E. Widders. 1990. N and P preconditioning of small plugseedlings influence growth and yield of processing tomatoes. HortScience 25:655-657.

Granato, T.C. and D.C. Raper, Jr. 1989. Proliferation of maize (Zea mays L.) roots in response to localized supply of nitrate. J. Expt. Bot. 40:263-275.

Greenwood, D.J., A. Gerwitz, D.A. Stone, and A. Barnes. 1982. Root development of vegetable crops. Plant Soil 68:75-96.

Grünsted, M.J., M.J. Hedly, R.E. White, and P.H. Nye. 1982. Plant induced changes in the rhizosphere of rape (Brassica napa var. Emperald) seedling. I. $\mathrm{pH}$ changes and the increase in $\mathrm{P}$ concentration in the soil solution. New Phytol. 91:9-29.

Hardenburg, R.E., A.E. Watada, and C.Y. Wang. 1986. The commercial storage of fruits, vegetables, and florist and nursery stocks. U.S. Dept. Agr. Hdbk. 66.

Harrison-Murray, R.S. and D.T. Clarkson. 1973. Relationships between structural development and the absorption of ions by the root system of Cucurbita pepo. Planta 114:1-16.

Heydecker, W. and P. Coolbear. 1977. Seed treatments for improved performance-Survey and attempted prognosis. Seed Sci. Technol. 5:425-533.

Hinchee, M.A.W. and T.L. Rost. 1992. The control of lateral root development in cultured pea seedlings. III. Spacing intervals. Bot. Acta 105:127-131.

Hurren, N.G., S.M. Zeadan, and R.D. MacLeod. 1988. Lateral root development in attached and excised roots of Zea mays L. cultivated in the presence or absence of indol-3-yl acetic acid. Ann. Bot. 61:573-579.

Jackson, M.B. 1979. Rapid injury to peas by soil waterlogging. J. Sci. Food Agr. 30:143-152.

Jackson, M.B. and M.C. Drew. 1984. Effects of flooding on growth and metabolism of herbaceous plants, p. 47-128. In: T.T. Kozlowski (ed.) Flooding and plant growth. Academic, Orlando, Fla.

Jackson, W.T. 1955. The role of adventitious roots in recovery of shoots following flooding of the original root system. Amer. J. Bot. 42:816-819.
Kahn, B.A. 1985. Characterization of lodging differences in paprika pepper. HortScience 20:207-209.

Kahn, B.A. and P.J. Stoffella. 1991. Nodule distribution among root morphological components of field-grown cowpeas. J. Amer. Soc. Hort. Sci. $116: 416-420$

Kahn, B.A., P.J. Stoffella, R.F. Sandsted, and W.L. Hymes. 1981. Effect of between-row spacing, population, and genotype on growth and yield of black beans. J. Amer. Soc. Hort. Sci. 106:719-723.

Kahn, B.A., P.J. Stoffella, R.F. Sandsted, and R.W. Zobel. 1985. Influence of flooding on root morphological components of young black beans. J. Amer. Soc. Hort. Sci. 110:623-627.

Karmoker, J.L. and R.F. Van Steveninck. 1979. The effect of abscisic acid on sugar levels in seedlings of Phaseolus vulgaris L. cv. Redland Pioneer. Planta 146:25-30.

Khan, A.A. 1992. Preplant physiological seed conditioning. Hort. Rev. 13:131179.

Keller, B. and C.J. Lamb. 1989. Specific expression of a novel cell wall hydroxyproline-rich glycoprotein gene in lateral root initiation. Genes Dev. 3:1639-1646.

Kent, L.M. and A. Lauchli. 1985. Germination and seedling growth of cotton: Salinity-calcium interactions. Plant Cell Environ. 8:155-159.

Klepper, B. 1990. Root growth and water uptake, p. 281-322. In: B.A. Stewart and D.R. Nielsen (eds.). Irrigation of agricultural crops. Amer. Soc. Agron., Madison, Wis.

Klepper, B. 1991. Crop root system response to irrigation. Irrigation Sci. 12:105-108.

Klepper, B. and R.W. Rickman. 1991. Predicting root development of crop plants, p. 85-99. In: T. Hodges (ed.). Predicting crop phenology. CRC Press, Boca Raton, Fla.

Kramer, P.J. 1951. Causes of injury to plants resulting from flooding of the soil. Plant Physiol. 26:722-736.

Latimer, J.G. 1991. Mechanical conditioning for control of growth and quality of vegetable transplants. HortScience 26:1456-1461.

Latimer, J.G. and C.A. Mitchell. 1988. Effects of mechanical stress or abscisic acid on growth, water status, and leaf abscisic acid content of eggplant seedlings. Scientia Hort. 36:37-46.

Lauchli, A. and E. Epstein. 1990. Plant responses to saline and sodic conditions. In: K.K. Tanji (ed.). Agricultural salinity assessment and management. Amer. Soc. Civil Eng. Manuals Rpts. Eng. Practice 71:113-137.

Leskovar, D.I. and D.J. Cantliffe. 1991. Tomato transplant morphology affected by handling and storage. HortScience 26:1377-1379.

Leskovar, D.I. and D.J. Cantliffe. 1992. Pepper seedling growth response to exogenous abscisic acid. J. Amer. Soc. Hort. Sci. 117:389-393.

Leskovar, D.I. and D.J. Cantliffe. 1993. Comparison of plant establishment method, transplant or direct-seeding, on growth and yield of bell pepper. J. Amer. Soc. Hort. Sci. 118:17-22.

Leskovar, D.I., D.J. Cantliffe, and P.J. Stoffella. 1989. Pepper (Capsicum аппиит L.) root growth and its relation to shoot growth in response to nitrogen. J. Hort. Sci. 64:711-716.

Leskovar, D.I., D.J. Cantliffe, and P.J. Stoffella. 1990. Root growth and rootshoot interaction in transplants and direct seeded pepper plants. Environ. Expt. Bot. 30:349-354.

Leskovar, D.I., D.J. Cantliffe, and P.J. Stoffella. 1994. Transplant production systems influence growth and yield of fresh market tomatoes. J. Amer. Soc. Hort. Sci. 119:662-668.

Leskovar, D.I. and R.R. Heineman. 1994. Growth of 'TAM-Mild Jalapeño-1' pepper seedlings as affected by greenhouse irrigation systems. HortScience 29:1470-1474.

Letey, J., L.H. Stolzy, and G.B. Blank. 1962. Effect of duration and timing of low soil oxygen content on shoot and root growth. Agron. J. 54:34-37.

Liptay, A. 1987. Field survival and establishment of tomato transplants of various age and size. Acta Hort. 220:203-209.

Liu, A. 1980. The survey of the nutrient status in the soil-root interphase. Current Progress Soil Sci. China 8:1-11.

Lynch, J. and J.J. van Beem. 1993. Growth and architecture of seedling root of common bean genotypes. Crop Sci. 33:1253-1257.

MacIsaac, S.A., V.K. Sawhney, and Y. Pohorecky. 1989. Regulation of lateral root formation in lettuce (Lactuca sativa) seedling roots: Interacting effects of $\alpha$-naphthaleneacetic acid and kinetin. Physiol. Plant. 77:287-293.

MacLeod, R.D. 1990. Lateral root primordium inception in Zea mays L. Environ. Expt. Bot. 30:225-234.

Marschner, H. and V. Romheld. 1983. In vivo measurement of root induced $\mathrm{pH}$ changes at the soil-root surface: Effect of plant species and nitrogen source. Z. Planzenphysiol. Bodenkd. 111:241-251.

Marschner, H., V. Romheld, W.J. Horst, and P. Martin. 1986. Root-induced changes in the rhizosphere. Importance for mineral nutrition on plants. Z. Planzenernaehr. Bodenkd. 119:441-456.

McCully, M.E. and A.J. Canny. 1988. Pathways and processes of water and nutrient movement in roots. Plant Soil 111:159-170. 
McKee, J.M.T. 1981. Physiological aspects of transplanting vegetables and other crops. I. Factors which influence re-establishment. Hort. Abstr. 51:265-272.

Melchior, W. and E. Steudle. 1993. Water transport in onion (Allium cepa L.) roots. Plant Physiol. 101:1301-1315.

Miller, D.E. 1986. Root systems in relation to stress tolerance. HortScience 21:963-970.

O'Toole, J.C. and W.L. Bland. 1987. Genotypic variation in crop plant root systems. Adv. Agron. 41:91-145.

Papadopoulos, A.P. and H. Tiessen. 1987. Root and air temperature effects on the elemental composition of tomato. J. Amer. Soc. Hort. Sci. 112:988993.

Phene, C.J., K.R. Davis, R.B. Hutmacher, B. Bar-Yosef, D.W. Meek, and J. Misaki. 1991. Effect of high frequency surface and subsurface drip irrigation on root distribution of sweet corn. Irrigation Sci. 12:135-140.

Portas, C.A.M. and J.J.F.B. Dordio. 1980. Tomato root systems: A short review with reference on tomatoes. Acta Hort. 100:13-125.

Poysa, V.W., C.S. Tan, and J.A. Stone. 1987. Flooding stress and the root development of several tomato genotypes. HortScience 22:24-26.

Reyes, E. and P.H. Jennings. 1994. Response of cucumber (Cucumis sativus L.) and squash (Cucurbita pepo L. var. melopepo) roots to chilling stress during early stages of seedling development. J. Amer. Soc. Hort. Sci. 119:964970.

Rost, T.L. and H. Toriyama. 1991. A comparative analysis of the root systems of light- and dark-grown seedlings of pea (Pisum sativum cv. Alaska). Plant Sci. 75:117-121.

Rowse, H.R. 1974. The effect of irrigation on the length, weight, and diameter of lettuce roots. Plant Soil 40:381-391.

Russell, R.S. 1977. Plant root systems: Their function and interaction with the soil. McGraw-Hill, Berkshire.

Sanders, D.C., T.A. Howell, M.M.S. Hile, L. Hodges, and C.J. Phene. 1989. Tomato root development affected by traveling trickle irrigation rate. HortScience 24:930-933.

Schaller, G. 1987. pH changes in the rhizosphere in relation to the $\mathrm{pH}$-buffering of soils. Plant Soil 97:439-444.

Schuurman, J.J. and M.A.J. Goedewaagen. 1971. Methods for examination of root systems and roots. 2nd ed. Pudoc, Wageningen, The Netherlands.

Smucker, A.J.M., J.C. Ferguson, W.P. DeBruyn, R.K. Belford, and J.T. Ritchie. 1987. Image analysis of video-recorded plant root systems, p. 6780. In: H.M. Taylor (ed.). Minirhizotron observation tubes: Methods and applications for measuring rhizosphere dynamics. Special Publ. 50. Amer. Soc. Agron., Madison, Wis.

Snapp, S.S. and C. Shennan. 1992. Effects of salinity on root growth and death dynamics of tomato, Lycopersicon esculentum Mill. New Phytol. 121:7179.

Steudle, E. , R. Oren, and E.D. Schulze. 1987. Water transport of maize roots. Measurements of hydraulic conductivity, solute permeability, and of reflection coefficient of excised roots using the root pressure probe. Plant Physiol. 84:1220-1232.

Stoffella, P.J. 1983. Root morphological characteristics of field-grown tomatoes. HortScience 18:70-72.

Stoffella, P.J. and H.H. Bryan. 1988. Plant population influence growth and yield of bell peppers. J. Amer. Soc. Hort. Sci. 113:835-839.

Stoffella, P.J. and B.A. Kahn. 1986. Root system effects on lodging of vegetable crops. HortScience 21:960-963.

Stoffella, P.J., M. Lipucci DiPaola, A. Pardossi, and F. Tognoni. 1988a. Root morphology and development of bell peppers. HortScience 23:1074-1077.

Stoffella, P.J., M. Lippucci DiPaola, A. Pardossi, and F. Tognoni. 1991. Rhizosphere $\mathrm{pH}$ influences early root morphology and development of bell peppers. HortScience 26:112-114.

Stoffella, P.J., M. Lipucci DiPaola, A. Pardossi, and F. Tognoni. 1992. Seedling root morphology and development and shoot growth after seed priming or pregermination of bell peppers. HortScience 27:214-215.

Stoffella, P.J., A. Pardossi, and F. Tognoni. 1988b. Temperature and seed treatment effects on taproot growth of young bell peppers. Adv. Hort. Sci. $2: 8-10$.
Stoffella, P.J., R.F. Sandsted, R.W. Zobel, and W.L. Hymes. 1979a. Root characteristics of black beans: I. Relationship of root size to lodging and seed yield. Crop Sci. 19:823-826.

Stoffella, P.J., R.F. Sandsted, R.W. Zobel, and W.L. Hymes. 1979b. Root characteristics of black beans: II. Morphological differences among genotypes. Crop Sci. 19:826-830.

Stoffella, P.J., R.F. Sandsted, R.W. Zobel, and W.L. Hymes. 1981. Root morphological characteristics of kidney beans as influenced by within-row spacing. HortScience 16:543-548.

Takahashi, H., T.K. Scott, and H. Suge. 1992. Stimulation of root elongation and curvature by calcium. Plant Physiol. 98:246-252.

Tanaka, N. 1964. Studies on the three types of root system formation in leguminous crop plants. Agr. Bul. Sage Univ. 20:31-43.

Tanaka, N. 1977. Studies on the growth of root systems in leguminous crops. Agr. Bul. Sage Univ. 43:1-82.

Taylor, H.M. 1986. Methods of studying root systems in the field. HortScience 21:952-956.

Tremblay, N. and A. Gosselin. 1989. Growth and nutrient status of celery seedlings in response to nitrogen fertilization and $\mathrm{NO}_{3}: \mathrm{NH}_{4}$ ratio. HortScience 24:284-288.

Varney, G.T., M.J. Canny, X.L. Wang, and M.E. McCully. 1991. The branch roots of Zea. I. First order branches, their numbers, sizes and division into classes. Ann. Bot. 67:357-364.

Wample, R.L. and R.M. Reid. 1978. Control of adventitious root production and hypocotyl hypertrophy of sunflower (Helianthus annum) in response to flooding. Physiol. Plant. 44:351-358.

Watts, S., J.L. Rodriguez, S.E. Evans, and W.J. Davis. 1981. Root and shoot growth for plants treated with abscisic acid. Ann. Bot. 47:595-602.

Weaver, J.E. 1926. Root development of field crops. McGraw-Hill, New York.

Weaver, J.E. and W.E. Bruner. 1927. Root development of vegetable crops. McGraw-Hill, New York.

Westgate, M.E. and J.S. Boyer. 1985. Osmotic adjustment and the inhibition of leaf, root, stem, and silk growth at low water potentials in maize. Planta 164:540-549.

Weston, L.A. and B.H. Zandstra. 1989. Transplant age and $\mathrm{N}$ and $\mathrm{P}$ nutrition effects on growth and yield of tomatoes. HortScience 24:88-90.

Widders, I.E. 1989. Pretransplant treatments of $\mathrm{N}$ and $\mathrm{P}$ influence growth and elemental accumulation in tomato seedlings. J. Amer. Soc. Hort. Sci. 114:416-420.

Widders, I.E. and O.A. Lorenz. 1982. Potassium nutrition during tomato plant development. J. Amer. Soc. Hort. Sci. 107:960-964.

Wien, H.C., P.L. Minotti, and V.P. Grubinger. 1993. Polyethylene mulch stimulates early root growth and nutrient uptake of transplanted tomatoes. J. Amer. Soc. Hort. Sci. 118:207-211.

Wightman, F., E.A. Schneider, and K.V. Thimann. 1981. Hormonal factors controlling the initiation and development of lateral roots. II. Effects of exogenous growth factors on lateral root formation in pea roots. Physiol. Plant. 49:304-314.

Wilcox, G.E. and C.L. Pfeiffer. 1990. Temperature effect on seed germination, seedling root development and growth of several vegetables. J. Plant Nutr. 13:1393-1403.

Youssef, R.A. and M. Chino. 1989. Root-induced changes in the rhizosphere of plants. I. pH changes in relation to the bulk soil. Soil Sci. Plant Nutr. 35:461-468.

Zeadan, S.M. and R.D. MacLeod. 1984. Some effects of indol-3-yl acetic acid on lateral root development in attached and excised roots of Pisum sativum L. Ann. Bot. 54:759-766.

Zobel, R.W. 1975. The genetics of root development, p. 261-275. In: J.G. Torrey and D.F. Clarkson (eds.). The development and function of roots. Academic, London.

Zobel, R.W. 1986. Rhizogenetics (root genetics) of vegetable crops. HortScience 21:956-959.

Zobel, R.W. 1989. Steady-state control and investigations of root system morphology, p. 165-182. In: J.G. Torrey and L.J. Winchip (eds.). Applications of continuous and steady-state methods to root biology. Klewer Academics, Rosdrecht, The Netherlands. 